\title{
Cultivate and Carry forward Socialist Core Values Based on Excellent Traditional Chinese Culture
}

\author{
Yinghui Ren \\ Department of Ideological and Political Theory Course \\ Wuhan Donghu University \\ Wuhan, China 430212
}

\begin{abstract}
It is the requirement of improving national cultural soft power and strengthening cultural self-confidence of Chinese nation to base on excellent traditional Chinese culture, in order to cultivate and carry forward socialist core values. The dialectical unification relations of excellent traditional Chinese culture and socialist core values and the combination of the two to realize the great rejuvenation of the Chinese nation make it possible to base on excellent traditional Chinese culture, in order to cultivate and carry forward socialist core values. Workers of philosophy and social sciences integrate excellent traditional cultural education in strengthening moral education and cultivating people in colleges, depend on new media technology and strengthen the effectiveness of cultivating and implementing socialist core values with the help of "Two Studies, One Action".
\end{abstract}

Keywords-excellent traditional Chinese culture; socialist core values; new media; Two Studies and One Action

\section{INTRODUCTION}

It is the work orientation for consolidation of mainstream ideology and improvement of Chinese cultural soft power to cultivate and carry forward socialist core values. Meanwhile, the General Secretary Xi Jinping stresses repeatedly, "We must base on the excellent traditional Chinese culture to cultivate and carry forward socialist core values". (1) Under the globalization pattern of social transformation, interest adjustment and cognitive differentiation, new media like network and mobile phones impact the cultural self-confidence and self-consciousness of the public especially young students. Workers of philosophy and social sciences should base on excellent traditional Chinese culture to cultivate and carry forward socialist core values, realizing the bilateral interaction and joint promotion of them.

\section{NECESSITY}

"Excellent traditional culture is indispensable spiritual home of Chinese nation." "The spread of socialist core values

Fund project: This paper is the phased achievement of Research on Influence of New Media Environment on Ideological and Political Education in Colleges(20140010), the Youth Fund Project of Wuhan Donghu University in 2014.

${ }^{\text {I }} \mathrm{Xi}$ Jinping. Opinions of Xi Jinping on Governance of the Country [M], Beijing: Foreign Languages Press, 2014:163

${ }^{2}$ Liu Aiwu. Carry forward Excellent Traditional Chinese Culture and Improve Contemporary Chinese Cultural Soft Power [J], Ideological and Theoretical Research, 2015(8):42 must base on traditional culture." (2) It shows General Secretary Xi Jinping stresses we should base on excellent traditional Chinese culture to cultivate and carry forward socialist core values. It is the demand to improve national cultural soft power and strengthen cultural self-confidence of Chinese nation.

\section{A. The Demand to Improve National Cultural Soft Power}

Under the background of globalization, the competition between countries refers to the competition of comprehensive national power. As a spiritual strength, culture plays an increasingly prominent role in it. The improvement of cultural competitiveness is an inevitable choice of developing countries to obtain cohesive force and creativity of nationality development in the fierce international competition and multicultural background.

As for the methods to improve national cultural soft power, it is stressed in Report of the 17th National Congress of CPC that, "Roundly recognize traditional Chinese culture ... strengthen the education of excellent Chinese cultural tradition and use modern scientific and technological tools to develop the abundant cultural resources...reinforce the international influence of Chinese culture." (1) Obviously, it is accepted by people to improve national cultural soft power through inheriting excellent traditional Chinese culture.

The national cultural soft power includes the cultural cohesive force of countrymen and cultural influence on the international society. Excellent traditional Chinese culture is extensive and profound with powerful vitality and influence. For example, the fine traditions of Chinese people in "Selfcultivation, Family Harmony, State Governing and World Peace" for thousands of years, including the self-cultivation spirit like "Self-introspection should be practiced on daily basis", "Self-discipline and social commitment", "Do unto others as you would be done" and "Being nice", the family ethics like "Filial piety is the foundation of all virtues", "Connubial love" and "The son's mistakes should be blamed to his father's failure of teaching", the patriotic sentiments like "The whole world as one community", "I wish to be the first to worry about the nation's woes and the last to share in its prosperity" and "Everyone is responsible for his country",

Hu Jintao. Hold High the Great Banner of Socialism with Chinese Characteristics and Strive for New Victories in Building a Well-off Society in an All-round Way [N], PLA Daily, Oct.25, 2007 
have become the spiritual gene of Chinese nation passed on from generation to generation, becoming spiritual tie of cultural identity and national emotions. Furthermore, what belongs to the nation belongs to the world. The concepts of governing a state and diplomatic thinking in excellent traditional Chinese culture like "Harmony and peacefulness are prized", "Countries should not take the pursuit of wealth as benefits but take moral principles as benefits" and "Harmony in diversity" and "In hard time, try to seek self-development; in success, try to let others be benefited" have extremely high inimitable symbol, becoming the important cultural resources to unceasingly improve the international image and charm of China.

\section{B. The Demand to Strengthen the Cultural Self-Confidence of Chinese Nation}

With the development of digital technology, network technique and information communication technology, new media like network and mobile phones have become important platforms for people especially young people to get information since the 1990s. At present, most college students are "born after 1995", referring to the generation growing with new media. The change of media environment and the reform of reading mode have important influence on their way of thinking and behavioral habits. Visual stimulation of images and videos and complicated mass information lead to the absence of deep and systematic reading and thinking of college students; the impact of western culture on Chinese culture makes some young people go with the stream; the tendency of pragmatism of market economy constantly weakens traditional cultural education; the thinking of "fast-food culture" and "mass recreation" makes traditional culture recreational and vulgar. It makes some people ignore national culture or worship things foreign and fawn on foreign countries. "Hold an attitude of servility and admiration, lose confidence in tradition and blindly appreciate things of foreign countries." ${ }^{1}$ Cultural self-confidence is out of the question.

In order to strengthen cultural self-confidence of Chinese nation and realize the refulgence of Chinese culture, we should base on excellent traditional Chinese culture to cultivate and carry forward socialist core values. At the meantime, reconstruct our spiritual home, carry out reinterpretation and excavation of traditional cultural resources and guide young students to establish correct conception of history, show extraordinary charm of Chinese culture.

\section{FEASIBILITY}

The dialectical unification relations of excellent traditional Chinese culture and socialist core values and the combination of the two to realize the great rejuvenation of the Chinese nation make it possible to base on excellent traditional Chinese culture, in order to cultivate and carry forward socialist core values.

\footnotetext{
Zhao Xin, Li Huanqin. Analysis on Current Situation of Traditional Cultural Influence under New Media Environment [J], Forward Position, 2014(5): 134
}

\section{A. Excellent Traditional Chinese Culture and Socialist Core Values Have Dialectical Relationship.}

With unique and profound cultural gene, socialist core values have powerful cohesive and centripetal force; the excellent traditional Chinese culture has vigorous vitality as we cultivate and carry forward the socialist core values.

Firstly, excellent traditional Chinese culture is the important thinking resource of socialist core values. Theories cannot be created out of nothing. The socialist core values on three levels of country, society and individual base on excellent traditional Chinese culture. Although they are not absolutely equivalent, on national level, the prosperity, democracy, civilization and harmony root in "The nation is prosperous and the people are strong and powerful", "The people are the foundation of the state", "The emperor cultivates morality and the people are simple and honest", "theory that man is an integral part of nature" in traditional culture. On social level, celebrated dictums like "Follow what my heart desired, without transgressing what was right", "Inequality rather than want is the cause of trouble", "If the ruler himself is upright, all will go well even though he does not give orders", "Laws and decrees are foundation of people's life and state governance" highly correspond to freedom, equality, fairness and rule of law in socialist core values. On individual level, the famous sayings like "Everyone is responsible for his country", "Respect work and enjoy company", "Promise must be kept and action must be resolute" and "Being nice" contain rich contents of patriotism, dedication, integrity and amicability. Socialist core values form through absorbing excellent traditional Chinese culture and provisions with spirit of the time.

Secondly, cultivating and carrying forward socialist core values vitalizes excellent traditional Chinese culture with thousands of years of history, which is valuable cultural treasure of us. As the ideology formed in a specific historical period, culture reflects the will and thought of a class and embodies the value demand. With the development of the times, traditional culture must be modernized. The service objects and connotations will change corresponding. Socialist core values endow excellent traditional Chinese culture with new connotation of the times. The best way to modernize excellent traditional Chinese culture is to cultivate and practice socialist core values. The cultivation and practice of socialist core values activate and improve excellent traditional culture and make it have more concise expression and better comply with the realistic era significance.

\section{B. Inherit Excellent Traditional Chinese Culture, Cultivate and Carry Forward Socialist Core Values to Realize the Great Rejuvenation of Chinese Nation}

In the long history, Chinese culture is in dynamic development through taking the essence and discarding the dregs in social practice at different ages. Socialist core values are the light of life after modern interpretation and creative conversion of traditional culture.

The Chinese Dream of realizing the great rejuvenation of the Chinese nation needs the support of the powerful spiritual force of socialist core values. Excellent traditional Chinese 
culture is the particular symbol of Chinese nation under the multicultural background, providing abundant spiritual resources to realize the great rejuvenation of Chinese nation.

Cultivating and carrying forward socialist core values requires basing on excellent traditional Chinese culture which promotes the development of socialist core values and the prosperity of socialist culture. Finally, it promotes national prosperity and strength, national revival, free and integrated development of individuals, as well as the realization of the great rejuvenation of Chinese nation.

\section{PATHS}

The process that culture has influences is "a quite and silent and imperceptible process". (1) We should integrate excellent traditional Chinese culture in strengthening moral education and cultivating people in colleges, depend on new media technology and activities of "Two Studies, One Action", in order to make the cultivation of socialist core values effective.

\section{A. Integrate Excellent Traditional Chinese Culture in Strengthening Moral Education and Cultivating People in Colleges}

It observed in the Guidelines on Improvement of Excellent Traditional Chinese Cultural Education printed and distributed by the Ministry of Education in 2014 that, "Give full play to the important role of ideological and political theory course. Promote the close integration of ideological and political education with excellent traditional Chinese cultural education... Further enrich the teaching contents of ideological and political theory course, innovate in teaching methods to improve teaching effects". (2) Education is the foundation for inheritance of excellent traditional Chinese culture. The soul of education is to strengthen moral education and cultivate people. The integration of excellent traditional cultural education with moral education can make people practice socialist core values in the inheritance of excellent traditional culture.

Firstly, in theory teaching, integrate excellent traditional Chinese cultural education with the teaching of five ideological and political theory courses. It strengthens the cultural deposits of theoretical and political theory course, improves teaching effectiveness and deepens students' understanding of excellent traditional Chinese culture. Meanwhile, optional courses relevant to traditional Chinese culture should be provided for college students to enrich course system. Workers of philosophy and social sciences should consider how to find the coherence point of five ideological and political theory courses and excellent traditional Chinese culture to explain excellent traditional Chinese culture from different perspectives and levels.

\footnotetext{
(1) Guo Xueli, Gao Hongmei. Traditional Cultural Education and the Construction of Core Values of College Students [J], Journal of Inner Mongolia Normal University (Education Science), 2013(7): 49.

http://www.moe.edu.cn/publicfiles/business/html files/moe/s7061/201404/166 543.html
}

Secondly, in practical teaching, build and improve social practice system of excellent traditional culture. Organize activities with rich traditional cultural connotations in social practice of winter and summer vacation, youth volunteer activity and social activities for public good, in order to make college students understand excellent traditional Chinese culture meanwhile better inherit and carry forward excellent traditional Chinese culture. Make the best of social resources like museum, exhibition hall, ancient cultural relics, scenic spots and historic sites and educational bases and organize activities of theme practice to strengthen college students' cultural identity and cultural self-confidence. Moreover, educational elements of traditional festivals can be excavated. Diversified theme activities like classics reading contest, traditional cultural knowledge competition, painting and calligraphy exhibition, speech contest of stories of famous celebrities, reading report meeting, art festival and debate competition can be held in traditional festivals like Dragon Boat Festival and Tomb-sweeping Day, in order to carry forward excellent traditional Chinese culture in activities and construction of campus culture.

\section{B. Depend on New Media Technology and Enrich Carriers}

Nowadays, network and mobile phones have become important platforms for people to get information and communicate. New media become carrier to inherit excellent traditional Chinese culture. For example, carry out online education with the help of official websites of schools or websites providing excellent shared courses; discuss traditional culture through forum and post bar to realize interaction of teachers and students; establish class communication group and course discussion group through QQ and WeChat to send teaching contents and realize timely and interactive discussion; use digital information technology of new media and break through the limit of space and time to enrich the learning contents of traditional culture and make the plane and static culture three-dimensional and dynamic. For example, we can "directly listen to traditional folk music through digital players; simulate and touch physical cultural relics through virtual reality technology and visit historical cultural relics and remains through virtual interaction technology; view traditional folk art performance through digital image technology; understand Chinese Confucianism, Buddhism, Taoism and traditional culture of national minorities through three dimensional animation technology", (3) in order to display traditional Chinese culture more vividly, systematically and visually.

However, new media is a double-edged sword. Improper use will cause side effects. Therefore, in the inheritance of excellent traditional culture with the help of new media, we must strengthen the supervision and guidance, purify network space, in order to make new media become new carrier to carry forward excellent traditional Chinese culture and socialist core values.

\footnotetext{
${ }^{3}$ Peng Xin. Realistic Dilemma and Innovative Strategies of Inheritance of Traditional Culture in the New Media Era, Jiangxi Social Sciences, 2014(12): 237
} 
C. Strengthen the Communication Effects of Excellent

Traditional Culture with the Help of "Two Studies, One

Action"

"Study party constitution and party rules, study series of speech and become qualified party member" is an important practice to deepen inner-party education and a regular education for all party members, a crucial opportunity to base on excellent traditional Chinese culture, in order to cultivate and carry forward socialist core values. General Secretary once stressed on various occasions we must value excellent traditional Chinese culture, excavate the value of times in excellent traditional Chinese culture and make it become important sources of socialist core values. All party members learn Opinions of Xi Jinping on Governance of the Country and Readers of Series of Important Speeches of General Secretary Xi Jinping and attend Party class taught by branch secretary and realize "Two Studies, One Action". Party members play exemplary and vanguard role to make excellent traditional Chinese culture span time and space and become everlasting. The profound excellent traditional Chinese culture makes the cultivation and practice of socialist core values have more emotional appeal.

\section{CONCLUSION}

On the forum of undertakings of social sciences held on May 17, 2016, General Secretary Xi Jinping stressed countless great thinkers have left cultural heritages as vast as the open sea in the long history. We should integrate resources of Marxism, excellent traditional Chinese cultural resources and resources of philosophy and social sciences in foreign countries to build philosophy and social sciences of Chinese characteristics, make the most of basic cultural gene of Chinese nation adapt to modern culture and coordinate with modern society. It indicates directions for workers of philosophy and social sciences. We can provide powerful intellectual impetus to cultivate and carry forward socialist core values and realize the great rejuvenation of the Chinese nation if we base on excellent traditional Chinese culture, excavate essence of thoughts and promote the modern conversion and innovative development of traditional culture.

\section{REFERENCES}

[1] Yang Ruisen. Correct Treatment and Evaluation on Two Cognitive Problems of Traditional Chinese Culture [J], Journal of Ideological and Theoretical Education, 2015(3):33

[2] Guo Jianning. Thinking on Contemporary Chinese Cultural Construction $[\mathrm{J}]$, Journal of Liaoning University (Philosophy and Social Sciences Edition), 2015(5):1 